\title{
Addendum
}

\section{New information on the type locality of Bulbostylis schomburgkiana (Cyperaceae).}

Key words: Cyperaceae, South America, Brazil, Bulbostylis.

This note is an addition to a previous article, "Two overlooked species of Bulbostylis (Cyperaceae) from South America," that appeared in Brittonia, volume 45 (Strong, 1993). It records new information on the type locality of Bulbostylis schomburgkiana.

Trichelostylis stricta was described by Nees in 1840 from a collection made by Robert Schomburgk (1023). It was later given the new name Fimbristylis schomburgkiana by Steudel in 1855. Recent study of this species indicates that it is a distinct species of Bulbostylis Kunth (Strong, 1993).

The label information on the holotype as well as on the three isotypes examined gave only British Guiana as the locality with no other details. Richard Schomburgk (1848) listed Trichelostylis stricta as occurring in wet, swampy savannahs and blooming in September in his account of the flora and fauna of British Guiana.

Using a series of lists published by George Bentham between the years 1840-1848 in which Robert Schomburgk's collections from South America are enumerated, Strong (1993) tried to place the locality of 1023 based on the localities of others of Schomburgk's numbers in the series close to 1023 . It was found that many of his numbers did run in a numerical sequence for a particular area or locality, e.g., 1014, 1015, and 1017 lie along the Rio Padamo in Venezuela. The number series between 1031 to 1059 with specific localities were collected in British Guiana (Roraima and surrounding areas). Based on this, Strong (1993) questioned whether Schomburgk could have been mistaken about the locality of his 1023 and whether it might actually have been col- lected in Venezuela along the Río Padamo, placing the type locality close to the only other known locality along the Rio Atabapo in Venezuela.

Recently, J. C. Lindeman (U) brought to my attention a copy of the list of plants collected by Robert Schomburgk on his first trip to Guyana (British Guiana) typed from the manuscript lists at Kew Gardens $(K)$ by the late Bassett Maguire and later presented to the New York Botanical Garden. The list is in numerical sequence by collection number. The following entry is made for number 1023: "Grass found on sand banks, Padawiri River, March." This indicates that the type locality of Bulbostylis schomburgkiana is along the Padauari River in Brazil.

Robert Schomburgk's route from Esmeralda, Venezuela to Georgetown, British Guiana, in the spring of 1839 (Schomburgk, 1841 ) indicates that on the 19th of March he navigated 9 miles up the Río Padauari from its mouth at the Río Negro to a settlement on the east bank of the river. On the morning of the 20th, he left the Padauari heading back towards the Rio Negro. The Rio Padauari has its headwaters in the Serra Curupira and drains into the Rio Negro. It is located at $0^{\circ} 07^{\prime} \mathrm{S}, 64^{\circ} 08^{\prime} \mathrm{W}$ in the state of Amazonas, Brazil. The only other known locality for Bulbostylis schomburgkiana is in the Amazonas territory of Venezuela along the Río Atabapo at Guarinuina. The Venezuelan locality lies approximately 560 km NW of the type locality.

Schomburgk, M. R. 1848. Reisen in British Guiana in den Jahren 1840-1844. Vol. 3. Leipzig.

Schomburgk, R. H. 1841. Journey from Esmeralda, on the Orinoco, to San Carlos and Moura on the Rio Negro, and thence by Fort San Joaquim to 
Demerara, in the Spring of 1839. J. Roy. Geogr. Soc. 10: 248-267.

Strong, M. T. 1993. Two overlooked species of Bulbostylis (Cyperaceae) from South America. Brittonia 45: 162-168.
Mark T. Strong

Department of Botany, MRC/166

Smithsonian Institution

Washington, D.C. 20560, U.S.A.

\section{The Rupert Barneby Award}

The New York Botanical Garden is pleased to announce that Dr. Andrê Mauricio de Carvalho, of the Centro de Pesquisas do Cacau, Itabuna, Brasil, and Prof. Ricardo Vanni, of the Instituto de Botánica del Nordeste, Corrientes, Argentina, are the recipients of the 1993 Rupert Barneby Award. Dr. Carvalho will use his award to continue his work on a taxonomic treatment of New World Dalbergia. Prof. Vanni will be able to further his studies of Zornia sect. Anisophylla in South America and of Stylasanthes for the floras of Argentina and Paraguay.

The New York Botanical Garden also invites applications for the 1994 Rupert Barneby Award. The award of $\$ 1000.00$ is to assist researchers planning to come to The New York Botanical Garden to study the rich collection of Leguminosae. Anyone interested in applying for the award should submit their curriculum vitae, a letter describing the project for which the award is sought, and how the collection at NYBG will benefit their research. Travel to NYBG should be planned between January 1, 1995 and January 31, 1996. The letter should be addressed to Dr. Enrique Forero, Director, Institute of Systematic Botany, The New York Botanical Garden, Bronx, NY 104585126 USA, and received no later than December 2, 1994. Announcement of the recipient will be made by December 16 th. Anyone interested in making a contribution to THE RUPERT BARNEBY FUND IN LEGUME SYSTEMATICS, which supports this award, may send their check, payable to The New York Botanical Garden, to Dr. Forero. 